\title{
Economics and Economic Order of Societies*
}

\author{
Zbigniew Hockuba ${ }^{* *}$
}

Departing from the distinction proposed by J. Buchanan between thinking in economics in terms of the theory of choice and analysis in categories of exchange and coordination, we claim that the Hayekian concept of economic order has a significant heuristic potential and can be fruitfully used to explain some important socio-economic phenomena. The goal of this paper is to confirm this claim through the application of the concept of economic order in the analysis of economic transformation and the discussion of the relation between economic order and moral norms. The paper is organised as follows. Section I contains introductory remarks. In section II, the two systems of economic thinking and reasoning: the theory of choice and analysis in categories of exchange and coordination are briefly presented. Section III contains a discussion of the concept of economic order, its origin, relation to the Freiburg School notion Ordo, and J. Buchanan's perspective on the market and exchange. In section IV, two areas of the application of the concept of economic order are presented: a) systemic transformation as a change in formal and informal institutions, their subjective representation by economic agents and the complex economic order, b) a relation between economic order and moral norms. Conclusions are drawn in section $V$.

Keywords: systems of economic thinking, theory of choice, concept of economic order, systemic change, institutional scaffolds, moral order.

Submitted: 08.03.2021 | Accepted: 16.06.2021

\section{Ekonomia i porządek ekonomiczny społeczeństw}

Bazując na zaproponowanym przez J. Buchanana rozróżnieniu pomiędzy myśleniem w ekonomii w ramach teorii wyboru oraz analiza $w$ kategoriach wymiany $i$ koordynacji, twierdzimy, że Hayekowska koncepcja porzadku ekonomicznego ma znaczny potencjat poznawczy i może być owocnie stosowana w badaniach wielu ważnych zjawisk spoteczno-ekonomicznych. W celu uzasadnienia tego twierdzenia, wykorzystujemy koncepcje porzadku ekonomicznego do analizy zjawiska transformacji systemowej, a także do określenia relacji pomiędzy porzadkiem ekonomicznym a normami moralnymi. Artykut ma następująca strukturę. Część I zawiera uwagi wprowadzajace. W części II zostaty zwięźle zaprezentowane dwa systemy

\footnotetext{
This is a revised version of a paper prepared for the Summit of the World Think Tanks: Tendencies of Social Sciences and the Humanities in the 21st Century, which was held by the Chinese Academy of Social Sciences, 2-3 November 2000, Beijing, China. I have discovered it recently in my annals and found that despite the passage of time its content is relevant, and the Hayekian concept of economic order can be fruitfully used to explain important current socio-economic phenomena, e.g. transition reversal which occurs in some post-socialist countries in Central and Eastern Europe.

** Zbigniew Hockuba - dr hab., prof. ucz., Faculty of Management, University of Warsaw, Poland, https:// orcid.org/0000-0002-7791-8384.

Correspondence address: Faculty of Management, University of Warsaw, Szturmowa 1/3, 02-678 Warsaw, Poland; e-mail: zhockuba@wz.uw.edu.pl.
} 
myślenia ekonomicznego: teoria wyboru oraz analiza $w$ kategoriach wymiany $i$ koordynacji. Część III przedstawia koncepcję porzqddku ekonomicznego, jej źródta, relację do pojęcia Ordo Szkoty Freiburskiej, oraz J. Buchanana ujęcie rynku i wymiany. Z kolei w cześsi IV pojęcie porzadku ekonomicznego zostato zastosowane do analizy: a) transformacji systemowej jako zmiany $w$ sferze instytucji formalnych i nieformalnych oraz $w$ ich odzwierciedleniu $w$ subiektywnej sferze gospodarujacych podmiotów; b) relacji pomiędzy porządkiem ekonomicznym a normami moralnymi. Część V zawiera konkluzje.

Słowa kluczowe: systemy myślenia ekonomicznego, teoria wyboru, koncepcja porządku ekonomicznego, zmiana systemowa, instytucje, normy moralne.

JEL: B490, B530, P210

\section{Introduction}

Economics is a social science, and it is commonly believed that it is the most scientific of all social sciences. This opinion is due to its successes in formalisation and mathematisation and a broad use of statistical and econometric methods. In the second half of the 20th century, economics began to be dominated by progressing formalisation. This development has led to certain anxieties which resulted from the fact that formalised economic theory left important aspects of human economic behaviour outside its field of interest. As J. Buchanan rightly pointed out, growing formalisation and mathematisation of economics has been possible due to narrowing of the area of analysis down to the problem of choice between alternatives under conditions of given, scarce resources. Thinking in the categories of the logic of choice directed the development of economics on the tracks leading to applied mathematics, and economics itself acquired features of mathematics of social engineering (Buchanan, 1979, p. 24). Opposition to the outlined trend in development of economics emerged already in the 1930s, when F.A. von Hayek (1937) presented the economic problem as a co-ordination of individual choices. In recent years, J. Buchanan demonstrated that specifying the subject of economic analysis in categories of exchange and co-ordination broadens our understanding of economic phenomena. It incorporates into analysis real human interactions in the process of economic activity as well as economic institutions which act as forms of co-ordination of these activities. It also gives economics institutional and social dimensions.
The aim of this paper is to point out heuristic potential of the notion of economic order which falls under the field of institutional economics. In the next section, I outline the difference between two mentioned systems of thinking in economics: the logic of choice and the problem of exchange and co-ordination. Section III presents an outline of the notion of economic order, while in section IV, I present two areas in which this concept can be applied. First, I show that the notion of economic order can be usefully utilised for a description and explanation of a systemic transformation. Secondly, I point out the fact that it creates a possibility to incorporate ethical concerns into economic analysis. In the final section, I conclude that the application of the Hayekian concept of economic order can be fruitfully extended to analysis of those phenomena which are in a process of change and their structures show a high degree of complexity.

\section{Two Systems of Economic Thinking: Logic of Choice Versus the Problem of Exchange and Co-ordination}

Two, not entirely integrated systems of thinking co-exist in contemporary economics. The first perceives the nature of the economic problem in choice and allocation of scarce resources among alternative competing aims. This is the commonly known problem of choice and allocation, familiar to all those who have had even superficial contact with economics. Allocative decisions, or economic choices, made by every economic agent - households, firms, and government agencies - constitute the solution of the economic problem of the society, 
i.e. the discovery (choice) of such a vector of production and exchange and a vector of prices which ensure maximum of profits and utility to the participants of the economic process. The problem of allocation has existed in economics at least since the late nineteenth century (Walras). However only Lord Robins (1932) recognised it as the principal domain of economics. Since then, the concept of logic of choice dominated the system of thinking of economists. Definition of the economic problem in terms of allocation - logic of choice - established economics on a specific trajectory of development. Because the utility maximising choice, after introduction of certain simplifying assumptions, allows itself to be represented in the form of a mathematical problem, the economic man received its mathematical representation in the form of a consistent set of preferences, while a firm was represented through a cost curve and a demand function. Underlying them was the assumption of rationality or optimisation under given constraints. Progressing formalisation of the problem quickly led to the "transformation" of economics into mathematics of social engineering - a term coined by J. Buchanan (1979, p. 24), and models of the consumer and the firm became far from a realistic representation of economic man. Referring to this phenomenon Ronald Coase (1990, p. 3) wrote: "We have consumers without humanity, firms without organisation, and even exchange without markets."

The above presentation of the system of thinking in categories of the theory of choice is simply an outline of the problem. In a broader analysis one should point out that the solution to the problem of allocation is completely neutral with respect to the institutional structures of the process of exchange and organisation of industry. In other words, with given preferences, resources, and technology, the optimal result of allocation is the same under the conditions of free market and in a centrally planned economy (Bernholtz \& Breyer, 1984, pp. 42-43). Without expanding on this conclusion, we can point out that it is true only in the theoretical world with no transaction costs, a result based on the Coase theorem (1994, pp. 10-11). Because this world does not exist in reality and transaction costs are always greater than zero, the institutional structure of the economy is important and significantly influences the process of allocation and production results in a society. R. Coase, quoted above, commenting on this issue, wrote: "it makes little sense for economists to discuss the process of exchange without specifying the institutional setting within which the trading takes place since this affects the incentives to produce and the costs of transacting. I think this is now beginning to be recognised and has been made crystal clear by what is going on in Eastern Europe today. The time has surely gone in which economists could analyse in great detail two individuals exchanging nuts for berries on the edge of the forest and then feel great that their analysis of the process of exchange was complete, illuminating though this analysis may be in certain respects. The process of contracting needs to be studies in real world setting" (1994, pp. 10-11). Similar conclusions were reached by D. North (in the theory of institutional change, 1990), J. Buchanan (in constitutional economics, 1985) and a growing circle of other authors.

Abandonment of the theoretical world of no transaction costs introduces us into another system of thinking in economics in which exchange and co-ordination constitute the nature of the economic problem. Let's explain this approach based on the example given by J. Buchanan (1979, pp. 27-28). Buchanan analyses economic activity of Robinson Crusoe before the arrival of Friday onto the island. The problem facing Crusoe is the problem of economic choice which we described above: optimal allocation of scarce resources among alternative goals. At the point of Friday's arrival, Crusoe establishes social relations with another human being. According to Buchanan, it is a moment significantly changing Crusoe's position. His economic choice becomes incorporated in a structure of social relations. Completely new forms of activity arise: exchange, trade, agreement and contracts. As Buchanan writes: "Crusoe, if he chooses to avoid pure conflict, and if he realises that Friday's interests are likely to be different from his own, will recognise that mutual gains can be secured through co-operation, through exchange or trade. This mutuality of advantage that may be secured by different subjects as a result of cooperative arrangements, be these simple or complex, 
is the one important truth in our discipline" (1979, p. 28).

Friday's arrival onto the island creates a new analytical framework. Recognition of benefits from trade, the process of negotiation and attempts to reach agreements which divide benefits from exchange, and finally the exchange and control of agreements fulfilment are all phenomena that go beyond pure logic of choice. The analytical domain is expanded by the problem of co-ordination of individual plans and behaviour. In a more developed form of organisation of the process of exchange, we find the market (as a network of economic institutions), division of labour, allocation of human capital and knowledge, and the problem of gains resulting from taking advantage of individual skills, qualifications and the knowledge of place and time (Hayek, 1945). Differences in the organisation of the process of production and exchange as well as differences in the institutional structure co-ordinating economic activities become important. All this constitutes an important subject of economic analysis which makes the problem of exchange and co-ordination its principal focus of interest. This is a fundamental feature of another system of economic thinking (alternative to the logic of choice), which broadens our experience and points to gains from the analysis of institutional structures including the economic order of societies.

The two systems of economic thinking outlined above are two different analytical perspectives in economics. These are also two different analytical programmes within which we often ask different questions, use different terms and tools. Reality is understood differently. Thinking in terms of the logic of choice is dominant in economics, but we know today that narrowing the analysis to it would significantly impoverish our understanding of economic processes. The analytical system of the logic of choice takes us into the world of economic abstraction. As R. Coase writes (1994, p. 5): "What is studied is a system which lives in the minds of economists but not on earth. I have called the result 'blackboard economics'. The firm and the market appear by name but they lack any substance. The firm in mainstream economic theory has often been described as a 'black box'. And so it is." Thinking in terms of the problem of exchange and co-ordination brings us to realistic interactions between people, institutions, and organisation of exchange, industry and politics.

\section{The Concept of Economic Order}

Exchange and production take place in a specific institutional framework. This institutional framework consists of rules of behaviour, norms of activity which are supposed to lower transaction costs and limit uncertainty of economic agents. The market is a set of institutions facilitating exchange, and the firm can be treated as a "sum" of contracts made among different agents constituting the firm or forming exchange relationships with it. Institutions, apart from their role of lowering transaction costs and limiting uncertainty, structure the economic process itself introducing order into it. Rules and order are two sides of the same phenomenon. On the one hand, the notion of order can be defined as a composition of elements (of a certain entity) put together according to specified rules $^{1}$. On the other, the very notion of rules and regularity assumes existence of an ordered structure or an ordered process. In the following analysis, we shall review briefly the uses of the notion of economic order, and then conduct a more systematic analysis of this notion so that subsequently we can point out heuristic properties of this concept.

In the German language zone, a popular concept is that of Wirtschaftsordnung, a concept introduced to economic theory by the Freiburg School. This concept plays a central role in explaining the functioning of economic systems, differences between structures of these systems (centrally planned economy versus free market) and their regulatory mechanisms (Eucken, 1941). According to Eucken (1990, pp. 372-373), the notion of "order" has got a double meaning. First, economic order means all existing economic forms (Gesamtheit der realisierten Formen), which in the terminology of contemporary economics can be understood as the empirical structure of economic institutions. In this sense, Eucken writes, we talk about the economic order of Germany in 1945 or 1900. We examine specific economic orders of different economies of the 19th and 20th centuries which are in the process 
of change and which do not always ensure the equilibrium of the economic process. In the second sense, order is a structure corresponding to the nature of man and material world, ensuring harmony and equilibrium, constituting a hidden element of world's architecture. Eucken refers to this type of order as essential order (Wesensordnung), natural (Naturordmung) or Ordo. According to Eucken, Ordo becomes understandable and gains importance especially in these periods when the existing empirical order fails or is unjust. Absurdity of concrete conditions leads to a search of rational forms agreeing with human nature (Die Ordnung wird gesucht, welche - anders als die gegebenen Ordnungen - der Vermunft oder Natur der Menschen enspricht). The role of economic policy of the government is creation of conditions in which the rational essential order Ordo will be fully apparent (Eucken, 1990, p. 374).

The category of economic order is widely used in the economic analysis of Friedrich A. von Hayek. Hayek is convinced that without this notion one cannot understand the complex phenomena of contemporary world (Hayek, 1993). Like Eucken, Hayek distinguishes two kinds of order: made, exogenous, artificial order (gesetzte Ordnung) and self-generating, endogenous order (gewachsene Ordnung) which is referred to as spontaneous. Spontaneous order is a result of rules and regularities which are expressed in the behaviour of elements of a system in response to the environment's stimuli ${ }^{2}$. These regularities can change in time as spontaneous order is subject to evolution. Hayek points out that the spontaneous order of the market has a great advantage over the constructed order of central planning. The first, being built on the principle of freedom of individual agents, ensures full utilisation of decentralised, fragmented knowledge, which is impossible in a centralised planned order. As a result, the spontaneous order is creative, innovative, generates wealth, and the made order of the plan is closed, rigid and generates poverty.

Other authors also realise the heuristic opportunities embedded in the notion of economic order. James Buchanan (1992, pp. 18-19), speaking of possible directions of the development of economics in the 21st century, states that new institutional economics will almost certainly establish a dominant position, and that the perspective according to which the economy is "the order of social interactions" should gradually gain more and more supporters. North on the other hand uses three terms to define an ordered set of institutions which, similarly to Hayek's endogenous rules, determine the behaviour of economic agents. The three terms are the mentioned institutional matrix, institutional framework and the so-called scaffolds in the form of political structures, structures of property rights and informal constraints, norms and conventions, which maintain and direct individual and collective actions and impose order on them. North's illustrative terms are close in meaning to the notion of economic order because they refer to endogenous rules of behaviour of individuals and organisations which limit uncertainty, ensure regularity of actions and introduce order to the whole economic system.

Let's consider the notion of order in a more systematic way. The order of a system can be considered in static and dynamic frameworks. In the static framework, order is understood as a composition of elements put together according to specified rules. The result of such a composition is order and harmony. In the second, dynamic framework, we deal with an ordered process, regularities of behaviour in time, laws of evolution and development. In relation to an economic system, we can talk about economic order and about order of the economic process ${ }^{3}$. In the following analysis, we shall concentrate on the problems of economic order.

Economic order is a composition of elements of an economic system according to specified rules. Economic agents are the elements of this economic system. It is in behaviour of these agents that regularities which point to the existence of rules constituting order in a system become apparent (Hayek, 1993, vol. I). The rules which we refer to are North's institutions. "Institutions are the rules of the game in the society, or more formally, are the humanly devised constraints that shape human interaction" (North, 1997, p. 2). There are two types of institutions: informal and formal. Informal institutions develop and evolve spontaneously in the environment of repeated interactions among the participants of exchange. It is difficult to define 
them precisely, though in this context we usually mention routines, conventions, customs and traditions which are found in a given society, are part of its culture and are passed on from generation to generation in the process of knowledge transmission (North, 1997, p. 4; 1990, p. 37). Formal institutions are rules and laws written and codified, referring to the field of exchange, agreements and contracts. The difference between the two types of institutions is, as North (1990, p. 46) writes, a difference of degree. The aim of both of them is limitation of uncertainty, structuring of and facilitating exchange, simply establishing order over social and economic interactions among people.

Institutions exert their influence on economic structures through people's activities characterised by regularity. Thus the constraints which exist in the external environment are in one way or the other internalised, introduced to the subjective sphere of the individual The external moral, cultural or legal norm has got its subjective representation. It is a part of the subjectively experienced world of the economic agent, part of its knowledge and an element of its normative sphere. The external norm, without its subjective representation, does not successfully fulfil its regulatory functions. Its "extension" to the subjective world of the economic agent is a condition of its effectiveness. The rule of methodological subjectivism, which states that people's economic behaviour is dependent on their subjective perception of reality, their knowledge and norms, is thus confirmed. For illustration of this statement, Denzau and North (1994) use the term mental models, which suggests that agents create subjective models of their decision situation and act on the basis of these models. Results of actions either confirm or reject the subjective model. Exchange of information between the agent and its environment can lead to improvement of the model.

A summary of the above analysis is presented in Figure 1.

Figure 1. Institutions, economic agents and economic order

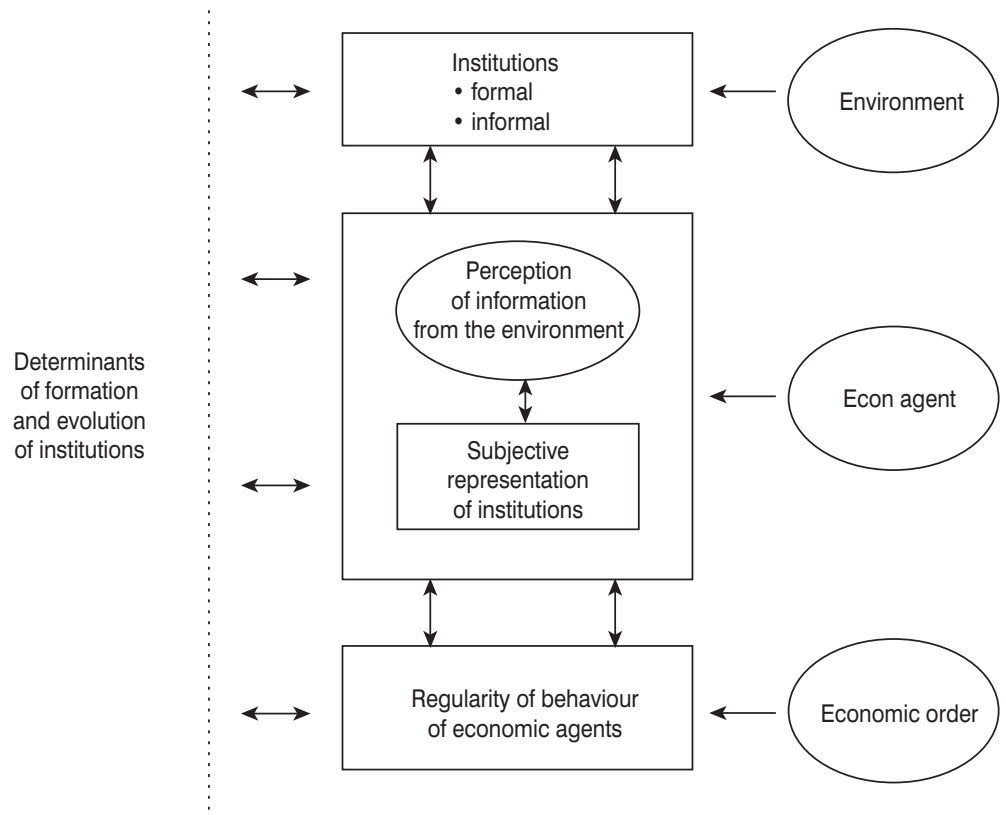

Figure 1 presents the basic argument according to which economic order is determined by institutions (rules), but the institutions (formal and informal) themselves are subject to "treatment" in the subjective sphere of the economic agent 
and only then determine its behaviour. The space between the environment and the agent combines exchange of information, its perception, the process of learning and verification of subjective models of decision situations. The quality of transmission of information and economic agents' knowledge are essential in determination of the economic order of the society.

\section{The Concept of Economic Order - Areas of Application}

The outlined notion of economic order can find particular use in these areas of economic analysis which are concerned with changing of a set of institutions, relations among formal and informal institutions, the influence of institutions of different type on output, as well as relationships between moral norms and functioning of an economy. In the following part of the discussion, we present an outline of an examination of two analytical problems in which the notion of economic order has been successfully applied.

\subsection{Transformation as a Change of the Economic Order}

The phenomenon of transformation, a systemic change which has been taking place in post-socialist countries, can be analysed from several perspectives. The analysis is dominated by the macroeconomic perspective in which problems of recession at the start of reforms, inflation stabilisation and internal and external balances become apparent. There is also a microeconomic perspective shedding light onto adaptive strategies of firms in the environment of liberalisation and stabilisation of the economy. There is also the institutional perspective, which seems to be particularly useful in the analysis of transformation, as the reform of economic order, and thus rules and formal and informal institutions which make it up constitute the nature of transformation. This fact has become more widely accepted and institutional analyses of problems of transformation have established a prominent place in economic literature. Below we outline selected institutional aspects of transformation applying the notion of economic order.

Transformation is a change of economic order. This change takes place through breakdown and collapse of institutional scaffolds of the centrally planned economy, passage through a period of chaotic adjustments (Hockuba, 1995) and building and consolidation of institutional framework of a free market economy. The whole process has got elements of self-organisation of the system, although it is the state which designs and "constructs" formal institutions at pace unparalleled in the natural process of cultural evolution.

In theoretical, stylised reconstruction of the process of transformation of order of the plan into the market order, we can distinguish conditions which are necessary for transformation to take place. These follow directly from the analysis conducted in the previous point. There are at least three necessary conditions:

1. formal institutions supporting order of the plan have to give way to the consistent and complete set of rules constituting the market order;

2. informal norms, conventions and habits associated with the centrally planned economy must be replaced with a consistent system of informal institutions of the market;

3. economic agents must internalise formal and informal rules so that their choices and behaviour fully complement each other in the market set of norms.

Of course, the above conditions of a successful transformation are themselves determined by factors which lie outside the domain of our analysis. Changes of formal rules are a function of reforms taking place in the sphere of politics. The pace, form and scope of democratisation of political life, political will of the elite, changes in the sphere of ideas and ideology will determine how fast a relatively complete matrix of formal institutions of the market will be created. However gigantic the undertaking - in a relatively short period of time hundreds and thousands of legislative acts are created - this condition of a successful transformation of economic order seems to be relatively easy to meet. In Poland, ten years after the start of reforms, the formal institutional framework has been significantly modified. Freedom of contracts, production and trade has become a norm. Private property is one of the main constitutional principles. Anti-monopolistic regulation protects development of competition treated as public good. There exist clear and relatively well specified rules 
of the capital market and financial markets are regulated with modern legal acts compatible with the practice of the market economy. The requirement of harmonisation of legislation with norms of the European Union, resulting from preparations for accession, maintains the momentum of the legislative process, and the harmonisation itself may be treated as an element of control over the formulated law 4 .

Construction of a new matrix of formal institutions creating the foundation of the market system is not sufficient, however, for the emergence of economic order of the market. For that it is necessary that informal constraints as well as subjective knowledge of economic agents change (conditions (2) and (3) of a successful transformation must be met). Douglas North (1997, p. 15) writes about this issue: "a change in the formal rules, specifically, property rights must be complemented by consistent informal constraints and effective enforcement to produce the desired results." In other words, correspondence of both types of institutions must exist as informal institutions complement formal, legal norms.

The conviction that informal constraints - conventions, habits, routines - change very slowly is firmly grounded in the theory of institutional change. They are a part of the cultural heritage of a society, system of ideas and ideology. Culture, as we already said, implies transmission of knowledge, values and norms through learning and imitation (see Sztompka, 2000, pp. 29-30; North, 1990, p. 37). Informal institutions contain thus cumulated experience and knowledge and are therefore somehow the "memory" of tested, numerously repeated modes of conduct in the past. In the situation of systemic discontinuity, revolution, radical change of formal rules, there appears a gap, a break, non-conformity between the two types of institutions. Economic order becomes dysfunctional. Quoting D. North on the radical systemic change again, we can say: "Perhaps most important of all, the formal rules change, but the informal constraints do not. In consequence, there develops an ongoing tension between informal constraints and the new formal rules, as many are inconsistent with each other The informal constraints had gradually evolved as extensions of previous formal rules (North, 1990, p. 91). As a result, the ensuing change is not as radical as it might appear at first sight. ${ }^{5}$

Let' $\mathrm{s}$ consider this issue in yet another context - the context of an individual who faces the problem of internalisation of changing norms, adjustment of ideas, knowledge, and subjective models of decision situations to the demands of the emerging market order. Let's ask how this process takes place, what is its dynamics, whether a radical "re-programming" of the subjective sphere of an economic agent is possible, and whether as a result we shall achieve regularities in behaviour which correspond to the market design. A complete answer to the above questions goes beyond the domain of economics and requires interdisciplinary knowledge on the frontier of psychology of learning, theory of information and institutional economics. However, the empirical analysis at our disposal suggests that "re-programming" of the subjective sphere of agents does not take place at once or in a short period ${ }^{6}$. It is undoubtedly a long-lasting process of learning of new ideas and patterns of behaviour. It is possible that a form of the phenomenon of path dependence occurs - a strong dependence on earlier choices, on experience, acquired standards and norms ${ }^{7}$.

\subsection{Moral Norms as an Element of Economic Order}

Contemporary economics largely assumes full separation from ethical concerns. Ethics is concerned with moral choice, norms and systems of values, while economics concerns itself with the economic choice. This separation of ethics and economics is however apparent only when we remain in the field of economics of logic of choice and the framework of allocation. The demarcation line is strongly blurred when we perceive the economic problem from the perspective of exchange and co-ordination. Exchange takes place in certain institutional conditions and is controlled by norms and rules of conduct. It is co-ordinated by an economic order and a set of moral norms is one of its elements. In this way, ethics enters the domain of economic activity and moral norms in a certain way determine output of a society. Using slightly different arguments, J. Buchanan (1994, p. 128) arrives at similar conclusions. He writes: "Does 
not my analysis here plunge economics into necessary discourse about morals? My response is perhaps clear, the attempted separation between economics and morals was, at best, an illusion that simply cannot be sustained."

Buchanan introduces moral norms into economic theory proving that they must be an argument in the utility function of agents' choice. Without getting into the details of the argument, we can say that utility from a given good to the same agent will differ depending on the way in which the good has been acquired. Most individuals prefer reciprocal dealings over theft, robbery, or fraud, although there are people who in specific situations choose non-reciprocal methods of acquiring goods. Moral preferences of individuals, groups and societies are revealed in this process of choice of rules of conduct and modes of economic activity. Thus, the market is not morally neutral. It has been "chosen" as a method of exchange of property rights assuming reciprocation and reciprocal dealings. The market as a system of institutions facilitating exchange and leading to exchange has been created as a result of imposition of constraints on behaviour by individuals, and thus is a result of a moral choice. Buchanan (1994, pp. 132, 134) expresses this in a slightly broader context: "The habits, customs, conventions and manners that characterise behaviour in many settings that we commonly observe are the outward manifestation of the endogenous constraints that are imposed on their own behaviour by the individuals who participate. It is possible to advance the positive claim that persons in social settings do constrain the set of choice alternatives they confront by imposing moral criteria on process of interaction with others."

From Buchanan's perspective, the market as a system of human interactions is a kind of moral order. Moral order is one of three ways of organising human relationships apart from moral community and moral anarchy. It is assumed that individuals respect each other's freedom, conduct exchange on the basis of reciprocation of services and trust each other to a certain degree. Moral anarchy is somehow the opposite of moral order. It is a system in which people treat each other just as means of realisation of their own goals and aims. There is no respect for autonomy and freedom of individuals and no reciprocation of services. Command, subordination of some relative to others and force are the basic social relations in its framework. Moral community, on the other hand, assumes a partial identification of goals of an individual with those of other people, which in the language of economics can be expressed in the term of interdependence of preferences. In the system of moral community, people sometimes act paying attention to others' interest more than to their own (for example, a mother placing the interest of her child above her own). They have no need to subordinate other individuals (Buchanan, 1981).

The three systems of human interactions mentioned above co-exist in all societies, though their proportions differ. Depending on these proportions, there are other implications for stability and governability. In a system of moral order, people act according to rules, but because not all individuals always follow them, the government ensures protection of laws and compliance with agreements. In conditions of moral anarchy, stability of the social structure is ensured by force and repression. The choice of specific rules of organisation of human relations, which is a moral choice, has therefore got an impact on management of an economy and also on its stability. Moral norms become an element of the economic order and as such determine economic phenomena and output of the society.

\section{Conclusions}

After presenting the concept of economic order, we have shown that it can be fruitfully used to discuss and explain some important features of economic transition from centrally planned to open market economy. Also, it allows for integrating moral norms into economic reasoning as values are part of mental models of economic agents and direct agents' behaviour. In other words, exchange takes place in a certain institutional framework and is controlled by norms and rules of conduct. It is also worth pointing out that the above two areas of application of the concept of economic order overlap. Transition is a systemic change which requires rebuilding of mental models. This can be a critical moment in the process of transforma- 
tion as mental models are quite stable and resistant to a quick overhaul. The transition process can thus get stuck or even reversed.

\section{Endnotes}

1 This is a Kantian definition referred to by F.A. von Hayek in the first volume of Law, Legislation and Liberty, entitled "Rules and Order" (1993, vol. I, p. 155).

2 Hayek (1993, vol. I, p. 36) defines the notion of order in the following way. It is: "a state of affairs in which a multiplicity of elements of various kinds are so related to each other that we may learn from our acquaintance with some spatial or temporal part of the whole to form correct expectations concerning the rest, or at least expectations which have a good chance of proving correct."

3 In the German language zone, in which the influence of the Freiburg School is still important, one uses the following terms to describe the above term: Wirtschaftsordnung and Handelnsordnung (see Gutmann, 1993). Wirtschaftsordnung means economic order. The meaning of Handelnsordnung, on the other hand, overlaps with our notion of order of the economic process. The consequence of the above distinction is two terms which refer to economic policy Ordnungspolitik and Prozesspotitik. Ordnungpolitik is the policy of institutional reform, while Prozesspolitik is the conventional economic policy (see also: Hockuba, 1995, pp. 74-77).

4 In the literature on the discussed problem, the lack of completeness and poor quality of formulated law are sometimes pointed out. For example, Winiecki (1999, pp. 205-6) writes that formulated rules are: "Inconsistent, ambiguous, badly formulated. If these weaknesses are revealed the rules change. Often, however, these changes are carried out in haste, in an accidental fashion, which results in a never-ending process of rules re-formulation. In Poland, in the first years of the process of transformation, some fundamental rules were modified more than dozen times." If we accept that "good" legislation is always created in a process of trial and error, is subject to evolution and adjustment to changing conditions, then changes of legal acts in the process of transformation, which is characterised by instability, will be more a rule than an exception. However, after ten years of intensive legislative work, the matrix of formal institutions not only has been significantly reformulated but is also becoming more complete and stable.

5 It is interesting to present the same problem in a sociological reflection of Piotr Sztompka (2000, p. 43). "The state of trauma - inconsi- stency, disruption of existing order, ambivalence - influences the sphere of culture: tension appears between the existing cultural commands (rules, values, customs, symbols, discourses, etc.) and emerging culture which is closer to the new social conditions. Culture is by its nature characterised by a certain degree of inertia. Therefore, the legacy of an earlier but outdated culture lives for longer than the system to which it functionally adhered and co-exists with new culture despite its mismatch with the new system This state of cultural split and ambivalence creates favourable conditions for development of a fully mature trauma."

6 The analysis of Katherine Verdery (1997) provides interesting information on the problem of emergence of transparent property rights in the process of transformation in Romania. She considers laws concerning privatisation of state-owned farms in Transylvania. According to Verdery, property is not only a set of rights and obligations. It contains complex semantic layers reflecting structures of power, social relations in local communities, knowledge systems of ideas and values of economic agents. Because of these factors, privatisation of a state-owned farm in Aurel Vlaic did not result in emergence of transparent exclusive property rights characterising mature free market economies. The local community of Aurel Vlaic, being involved in a network of social interactions, routines and conventions from the old period, opted for a fluid structure of property rights with stains of collective features.

7 Complexity of the discussed process is also confirmed in the following statement in Winiecki (1999, p. 206): "Not only the number, but also novelty of rules to be learnt makes the process of learning very difficult. In the worst scenario everything which economic agents have to learn is completely foreign, is not well understood and happens to be misinterpreted under the influence of informal rules, which on the other hand are rooted in the period of communism and earlier pre-communist past."

\section{References}

Bernholz, P., \& Breyer, F. (1984). Gnundlagen der Politischen Oekonomie. Tübingen: J.C.B. Mohr.

Buchanan, J. (1979). What should economists do?. Indianapolis: Liberty Fund.

Buchanan, J. (1992). Economics in the post-socialist century. In J.W. Hey (Ed.), The future of economics. Oxford: Blackwell.

Coase, R.H. (1990). The firm, the market and the law. Chicago.

Coase, R.H. (1994). Essays on economics and economists. Chicago. 
Denzau, A.T, \& North, D.C. (1994). Shared mental models: Ideologies and institutions. Kykios, 47(1).

Eucken, W. (1941). Die Grundlagen der Nationaloekonomie. Jena: Gustav Fischer.

Eucken, W. (1990). Grundsätze der Wirtschaftspolitik. Tübingen: J.C.B. Mohr.

Gutmann, G. (1993). Volkswirtschaftslehre.Eine ordungstheoretische Einfuehrung. Stuttgart: Kohlhammer.

Hayek, F.A. (1945). The use of knowledge in society. The American Economic Review, 35(4).

Hayek, F.A. (1993). Law, legislation and liberty. London: Routledge.

Hockuba, Z. (1995). Droga do spontanicznego porzadku (The road to spontaneous order). Warszawa: PWN.

North, D.C. (1990). Institutions, institutional change and economic performance. Cambridge University Press.

North, D.C. (1994). Economic performance trough time. The American Economic Review, 84(3).
North, D.C. (1997a). The contribution of the new institutional economics to an understanding of the transition problem [WIDER Annual Lectures 1]. WIDER, United Nations University, Helsinki.

North, D.C. (1997b). Understanding economic change. In J.M. Nelson, Ch. Tilly, \& and L. Walker (Eds.), Transforming post-communist political economies. Washington D. C.

Robins, L (1932). The nature and significance of economic science. London: Macmillan.

Sztompka, P. (2000). Trauma of the great change. Warszawa: ISP PAN.

Verdery, K. (1997). Fuzzy property rights, power, and identity in Transylvania's decollectivization. In J.M. Nelson, Ch. Tilly, \& L. Walker (Eds.), Transforming post-communist political economies. Washington D. C.

Winiecki, J. (1999). Formal and informal rules of conduct in the conditions of post-communist transformation. In E. Adamowicz (Ed.), Economy in the process of transition. Warszawa: SGH. 